\title{
1050 Applicability of perfusion MRI in monitoring cell-based therapy in a rabbit hindlimb ischemia model
}

\author{
Dorota A Kedziorek*1, Wesley D Gilson'2, Paromita Chatterjee', \\ Raymond C Boston ${ }^{3}$, Matthias Stuber ${ }^{1}$, Bernard E Kohl ${ }^{1}$, Gary Huang ${ }^{1}$, \\ Bradley Sieber ${ }^{1}$, Jeff WM Bulte ${ }^{1}$, Lawrence V Hofmann ${ }^{1}$ and \\ Dara L Kraitchman ${ }^{1}$
}

Address: ${ }^{1}$ Johns Hopkins University, Baltimore, USA, ${ }^{2}$ Siemens, Baltimore, USA and ${ }^{3}$ University of Pennsylvania, Kennett Square, PA, USA

* Corresponding author

from I Ith $^{\text {th }}$ Anual SCMR Scientific Sessions

Los Angeles, CA, USA. I-3 February 2008

Published: 22 October 2008

Journal of Cardiovascular Magnetic Resonance 2008, I0(Suppl I):AI75 doi:10.1 I86/I532-429X-I0-SI-AI75

This abstract is available from: http://jcmr-online.com/content/I0/SI/AI75

(c) 2008 Kedziorek et al; licensee BioMed Central Ltd.

\section{Introduction and purpose}

The successful treatment of Peripheral Arterial Occlusive Disease (PAOD) relies on the restoration of a sufficient blood supply to the ischemic tissue. Amongst many experimental therapies, cell-based therapy offers an option to enhance effective revascularization.

Magnetic Resonance Imaging (MRI) can be used to monitor the cell delivery, as well as, to serially interrogate the degree of cellular retention and engraftment but it lacks the spatial resolution to detect neovascularization. However, MR contrast-enhanced, first-pass perfusion can offer a non-invasive method to determine the functional consequences of this process.

The purpose of the study was to determine the efficacy of allogeneic mesenchymal stem cell (MSC) therapy in a blinded, placebo controlled trial in a rabbit PAOD model using non-invasive MRI.

\section{Materials and methods}

Mesenchymal stem cells were isolated from the bone marrow of male New Zealand White rabbits, expanded ( 3 passages), and magnetoelectroporated (MEP) with ferumoxides for magnetic labeling[1].
Hindlimb ischemia was induced by a minimally invasive, non-surgical, endovascular method where thrombogenic platinum coils were deployed in the superficial femoral artery[2]. Twenty-four hours after ischemia induction, female rabbits were blinded to receive $13 \times 10^{6} \mathrm{MEP}$ labeled MSCs $(n=6)$ or sham injections $(0.3 \mathrm{mg} / \mathrm{ml}$ of Fe in PBS) divided in six injections in the ischemic medial thigh.

First pass, saturation recovery perfusion MRIs (3 T Philips Achieva) were obtained after a Gadomer injection (0.01 $\mathrm{mmol} / \mathrm{kg} \mathrm{IV}$, Schering AG) prior to, 7 , and 14 days postcell injection. Signal-intensity time curves from MRI in the right and left calf were evaluated and compared to X-ray angiography (on day 15) and followed by postmortem histological analysis. A cross-section time series linear regression analysis with a $\mathrm{P}$ value $<0.05$ was considered statistically significant. Modified TIMI frame count, i.e. comparing the difference in time of filling of the popliteal bifurcation between the right non-ischemic and left ischemic limb on X-ray angiography was used to assess angiogenesis.

Histological analysis was performed on the medial thigh to determine the induction of neovascularization based on CD31 staining for endothelium and also to establish MSCs fate and vessel size. The CD31 positive capillaries 
were manually counted in 6 comparable areas of right and left hindlimbs and Poisson and Kruskal Wallis tests were used for the data analysis.

\section{Results}

At baseline, the difference in MR perfusion upslope time between ischemic (I) and non-ischemic (NI) limbs was worse in MSC-treated rabbits (5.0 $\pm 3 \mathrm{~s})$ vs. controls (3.7 $\pm 3 \mathrm{~s})$. At 2 weeks, TIMI frame counts showed similar therapeutic effect in MSC and sham groups ( $7.7 \pm 3$ vs. $7.3 \pm$ $3 \mathrm{~s}, \mathrm{P}=\mathrm{NS}$ ). However, MRI perfusion in MSC rabbits showed more improvement (difference decreased $2.1 \pm 1$ $\mathrm{s}, \mathrm{P}<0.04$ vs. baseline $)$ than controls $(1.0 \pm 1 \mathrm{~s}$ improvement, $\mathrm{P}=\mathrm{NS}$ ), which mirrored histological analysis results.

Increased capillary density in the left limb relative to the right limb based on histological analysis $(28 \pm 20 \mathrm{MSC}$ vs. $19 \pm 22$ control difference I vs. N, P = NS) was present in all animals except one control animal.

Furthermore, histological analysis confirms incorporation of the MSCs into the vessel walls.

\section{Conclusion}

In this preclinical model, MSC therapy show modest improvements in MRI perfusion relative to controls. MRI offers a non-invasive means to serially determine tissue perfusion without arterial access that is concordant with histological gold standards.

\section{References}

I. Walczak P, et al.: Magn Reson Med 2005, 54(4):769-774.

2. Liddell RP, et al.: J Vasc Interv Radiol 2005, I 6(7):991-998.
Publish with Bio Med Central and every scientist can read your work free of charge

"BioMed Central will be the most significant development for disseminating the results of biomedical research in our lifetime. " Sir Paul Nurse, Cancer Research UK

Your research papers will be:

- available free of charge to the entire biomedical community

- peer reviewed and published immediately upon acceptance

- cited in PubMed and archived on PubMed Central

- yours - you keep the copyright

Submit your manuscript here:

http://www.biomedcentral.com/info/publishing_adv.asp 